\title{
IMPORTANCE OF «WEAK» STATES DURING CONFLICTS: PORTUGUESE TRADE WITH THE UNITED STATES DURING THE REVOLUTIONARY AND NAPOLEONIC WARS*
}

CRISTINA MOREIRA

University of Minho ${ }^{\text {a }}$

JARI ELORANTA

Appalachian State University ${ }^{\text {b }}$

\begin{abstract}
This paper focuses on the analysis of weak states in the international trading system during the Revolutionary and Napoleonic crises, especially on Portugal's trade relations with the United States. We argue that the previous studies of the trade flows during these conflicts have not paid enough attention on smaller actors. Even though the Peninsular War caused severe disruption of agricultural production in Portugal, the United States, despite its strained relations with an ally of Portugal, Great Britain, became a key supplier for the Portuguese market. Clearly, the threatened position of the peninsula, and the need to supply the troops, awarded the Portuguese some room to manoeuvre in the international markets. Total war was not a constraint for all states - economic necessities trumped political and diplomatic concerns during the era of the first real-world wars. This situation was a temporary one, only to change after the conflict.
\end{abstract}

Keywords: Revolutionary and Napoleonic wars, Portugal, United States, trade, small states, weak states, total war

JEL Code: F10, N40, N71, N73

* Received 1 September 2010. Accepted 8 June 2011. The authors thank the anonymous referees and editors for extremely valuable comments, as well as the participants in the many conferences where the paper has been presented, and many colleagues who have provided valuable criticism. In particular, they thank Jari Ojala and Leos Müller for helpful comments, and Jeremy Land for valuable research assistance. Funding for this project has been provided by Fundação para a Ciência e Tecnologia, FEDER, POCI 2010, project POCI/HAR/59281/2004 "Portuguese Foreign Trade in the first half of $19^{\text {th }}$ Century», and Appalachian State University's University Research Council grant for 2010-2011.

a Department of Economics, University of Minho, School of Economics and Management, Campus Gualtar, 4710-057 Braga, Portugal. mcristina@eeg.uminho.pt

b Department of History, Appalachian State University, 224 Joyce Lawrence Lane, Boone, NC 28608, United States. elorantaj@appstate.edu 


\section{RESUMEN}

Este articulo tiene como punto de enfoque el análisis de los estados más débiles en el comercio internacional durante las crisis revolucionaria y napoleónica, con especial énfasis en las relaciones comerciales entre Portugal y los Estados Unidos. Defendemos que los estudios anteriores con respecto al comercio en estos conflictos no prestan la debida atención a los más pequeños. Aunque las Guerra de la Independencia había perturbado la producción agrícola en Portugal, los Estados Unidos, a pesar de haber tensado las relaciones con Gran Bretaña, un aliado de Portugal, se convirtieron en un proveedor clave para el Mercado portugués. La posición amenazada de la península y la necesidad de proveer al ejército, dio a los portugueses el margen de maniobra en los mercados internacionales. La guerra total no fue un obstáculo para todos los estados - las necesidades económicas se superponen a las cuestiones políticas y diplomáticas durante la época de la guerra del mundo real en primer lugar. Esa situación era temporal y cambiaría después del conflicto.

Palabras clave: Guerras Napoleónicas y Revolucionárias, Portugal, Estados Unidos, comercio, estados pequeños, estados más débiles, guerra total

\section{INTRODUCTION}

The analysis of the trade relations between Portugal and the United States from Revolutionary and Napoleonic wars and their aftermath can contribute to a deeper understanding of a period featuring massive international upheavals and disruptions of trade. Overcoming a major lack of studies regarding trade relations between Portugal and the United States in this period, a database has been created by Cristina Moreira, based on Portuguese and American quantitative and qualitative sources, which will be expanded in the next few years and eventually made available to other scholars. Trade relations were then analysed in conjunction with American quantitative data and several qualitative sources.

This paper taps into an important field of analysis, namely the discussion of the economic impacts of war on trade, as well as the role of neutral and/or weaker states in wartime situations. Many scholars have recently analysed the disruptions caused by major conflicts such as the world wars, and recent scholarship certainly puts the revolutionary wars and the contingent Napoleonic conflicts into the same category. However, these scholars have paid relatively little attention to the smaller (often neutral) players, such as the Nordic countries, in these wars, frequently assuming that they occupied an insignificant role in the conflict. Portugal, in particular, suffered three French invasions during Napoleon's rule, and, as it did not adhere to the Continental 
blockade, it experienced trade restrictions with several of its former suppliers. The United States, a weak military power at best at the time, became a major trading partner for Portugal, despite its strained relations with an ally of Portugal, Great Britain, and a key supplier for the Portuguese market, especially during the Continental System. It seems that some neutral and/or weaker nations were able to exploit the great demands of total war for their own economic benefit. However, beginning after 1812, the war pitting the United States against England brought new difficulties for the United StatesPortuguese trade, as U.S. shipments with cereals and flour were frequently captured by England. The reversal of the political situation after the second defeat of Napoleon and the Congress of Vienna once again changed the external environment for trade.

In this article, we want to analyse the changes in the Portuguese trade relations with the United States during an extremely turbulent period in history. We want to explore the kinds of changes, including structural, we see in the trade flows between these two weak states, especially whether the pressure of the war effort allowed more latitude for these states to explore their trade options; whether we see substantial changes, and what those changes would imply, in the types of goods exchanged over this complex period; what the significance of this trade was for both countries; and, finally, whether economic and business concerns overrode political and diplomatic obstacles in these trade relations, thereby opening up opportunities for the smaller/weaker states. Our argument is that weak states were able to expand their trade and discover new markets during such large and protracted conflicts, although this was, as in the case of Portuguese trade in this period, typically a shorter-term phenomenon. The networks gained during such conflicts would not last during peacetime, when market conditions changed.

\section{RESEARCH ON TRADE AND THE WORLD WARS: WHAT ROLE DID THE «WEAKER» STATES PLAY?}

The transition from the end of the $18^{\text {th }}$ century to the first decades of the $19^{\text {th }}$ century was marked by political instability in Europe. The expansion of the ideals of the French Revolution, and the spread of war driven by imperialistic France caused deep instability in Europe. Across the Atlantic, other wars were giving birth to new nations and the world was facing tremendous changes. The understanding of the trade relations between great powers, neutrals and/or smaller states, in this case between the United States and Portugal from 1796 to 1831 (thus including also the post-war impact), can provide a deeper insight into an understudied period in terms of international trade. We have created a new database on United States-Portuguese trade, based on Portuguese handwritten sources, which have opened up the possibility of obtaining a series of data for 36 consecutive years. This research was 
reinforced by other quantitative data and several qualitative sources, including: 1) Portugal's Balance of Trade with Foreign Nations and Portuguese Colonies - quantitative data covering the 36 years between 1796 and 1831; 2) Monthly Military General Account of Provisions from 1815 to $1816^{1}$; 3) Various qualitative sources, such as consular and military correspondence, memoirs and legislation ${ }^{2}$; 4) United States «Foreign Commerce and Navigation» from 1808 to $1814^{3}$. In addition, we utilised other statistical compilations. On the basis of these new data, we want to provide new perspectives on Portuguese trade in this crucial period, and engage the relevant debates in the field of economic history concerning economic warfare and the effect of conflicts on trade.

This paper taps into an important field of analysis, namely the discussion of the economic impacts of war on trade, as well as the role of smaller/ weaker states in wartime situations. In recent years, the economic impacts of warfare have become a lively topic of study among economists and historians (see, e.g. Harrison 1998; see also Broadberry and Harrison 2005) ${ }^{4}$. Many scholars - including Alan Taylor and Reuven Glick, Lance Davis and Stanley Engerman, as well as Ronald Findley and Kevin O'Rourke - have recently analysed the disruptions caused by major conflicts such as the world wars. Alan Taylor and Reuven Glick studied the indirect economic effects of wars, in particular World Wars I and II, with a large database, using an econometric gravity model. Their analysis, focusing on disruptions of trade and the subsequent economic losses, yielded clear results: Trade was clearly disrupted by wars, levels of trade did not return to pre-war levels, and these economic disruptions affected even those countries that were not directly involved in the conflict (Glick and Taylor 2005). Such impacts were clearly part of the overall story of the world wars and the entire $20^{\text {th }}$ century, which featured uneven economic performances, political instability, and major economic and political crises for Europe and the world as a whole. The average growth rates of most European states during the era of the world wars were modest at best compared to the late $19^{\text {th }}$ century performances or the so-called Golden Age, 1950-1973 (Maddison 1995; 2001).

${ }^{1}$ Arquivo Tribunal de Contas (Archives of the Audit Court): ER 5451.

${ }^{2}$ Arquivo Histórico Militar (Military Historic Archive) and Instituto dos Arquivos Nacionais Torre do Tombo (Institute of National Archives/Torre do Tombo).

${ }^{3}$ American State Papers - Legislative and Executive Documents of the Congress of the United States.

${ }^{4}$ Classic studies of this type include Alan Milward's works on the European war economies; see, for example, Milward (1965) and Milward (1977).

For a broad analysis of trade patterns and conflicts, see especially Findlay and O'Rourke (2007). Of course, one could also argue that the economic growth of the so-called Golden Age was partially premised on the reconstruction efforts arising from the war. Or, as, for example, Mancur Olson has argued, that the destruction of interest groups faciliated economic growth. See, for example, Olson (1982). However, the empirical support for the latter hypothesis seems mixed. See especially Gray and Lowery (1988, pp. 109-131) and Coates and Heckelman (1993, pp. 333-340). 
Many scholars have doubted the efficacy of economic warfare, which can range from fairly benign policy measures and pressure to outright warfare in the context of total war 6 . Lance Davis and Stanley Engerman have studied one particular form of economic warfare, naval blockades, spanning several centuries. They also emphasise both the costs and challenges of sustaining a successful blockade. For example, during the Napoleonic wars the legalities of blockades were not that clearly agreed upon, especially the issue of neutrality. The success of a blockade, as they point out, is often difficult to assess as well (Davis and Engerman 2006; see also Crouzet 1964, pp. 567-588). Periods of outright warfare, even blockades, can bring substantial opportunities for trade. As several scholars have emphasised, rising relative prices and substantial profits may be the answer to why such risky situations bring forth increases in trade (Thornton and Ekelund 2004) ${ }^{7}$. Moreover, recent scholarship, as presented by, for example, David Bell, certainly puts the revolutionary wars and the ensuing Napoleonic conflicts into the same category as the world wars (Bell 2007). Finally, Kevin O'Rourke has provided innovative insights into the Revolutionary and Napoleonic wars by focusing on the contraction of trade in particular. His results show that Great Britain was the least affected of the belligerents, whereas France and the United States suffered more. The welfare losses were around 5-6 per cent for the United States, which could be classified as substantial (O'Rourke 2006, pp. 123-149).

What are we trying to argue on the basis of these findings? First, the Revolutionary and Napoleonic wars were truly total wars based on the methods chosen by the belligerents. Second, the parameters of economic warfare were not very clearly defined or enforced. Third, the effects of the war spilled over to influence the relations between neutrals as well. Fourth, owing to the fact that these wars had an impact on the trade relations of all nations, many countries scrambled to find new outlets and sources for their trade. Fifth, the United States was particularly hard hit by these wars, which forced it to seek alternative trading partners and networks. Sixth, in this situation, the weaker and/or smaller states — such as Portugal — which was both weak and small - increased, albeit temporarily, owing to new market opportunities amidst rising profits. In sum, war, even total war, was not necessarily bad for everyone economically - there were opportunities to be exploited because of the heightened demand for commodities and war material. However, given the existing findings on such wars, it is highly likely that such advantages were short lived.

Scholars have paid relatively little attention to the smaller players in times of war, often assuming that they occupied an insignificant role in the conflict.

6 See, for example, Milward (2005) and Naylor (2001). On the variety of methods for engaging in economic warfare, see O'Leary (1985, pp. 179-206) and Førland (1993, pp. 151-162).

7 On the substantial scholarship focusing on the American Civil War blockades, see, for example, Wise (1991) and Hetherington and Kower (2009). 
«Small power» and «smaller state» as usually, erroneously, imply small geographic size. A more fitting definition can perhaps be found in the use of the term «weak state». This concept also applies to countries of considerable area, which were nonetheless weak players in the international system (Handel 1981; see also Eloranta 2002, pp. 44-67) ${ }^{8}$. Here we would posit that Portugal, despite also being a war zone for some of this period, was indeed such a state; a state that increased its international trade despite the difficulties brought on by the global conflict. The United States was a weak state, and for the most part in this period neutral too, given its short existence and limited military power.

Weak and/or neutral states, including, for example, the Nordic countries for most of this period (when they were not under occupation), served a vital function during a wartime trading system, when traditional trading networks between great powers were disrupted. As Leos Müller has shown, the concept of neutrality, implying impartiality during a particular conflict, evolved in the $17^{\text {th }}$ century, and neutral participation in trade reduced transaction costs among the belligerents, circumventing blockades and other trade restrictions. The ability to use neutral states as trading partners and carriers of goods prevented the wholesale collapse of the trading system during the era of the Revolutionary and Napoleonic conflicts (Müller 2001, pp. 30-47; 2004; see also Davis and Engerman 2006) ${ }^{9}$. Neutral states, which were treated differently by the belligerents based on past history and alliances, had to function in a treacherous economic environment, despite their efforts to pressure the great powers to recognise and respect their neutrality status, for example, by forming loose alliances between neutrals. To make this trading environment even more difficult, the British and Napoleon effectively instituted blockades on each other after 1802, developing later into the infamous Continental System by Napoleon in 1806 (Davis and Engerman 2006, particularly Chapter 2) ${ }^{10}$. Neutrals, such as the United States and the Nordic countries for some years of the period, tried to find their niches under these conditions, and although the risks were high, the payoffs were high too. Belligerent nations were desperate for goods and supplies. In fact, the Continental System increased trading opportunities for some nations, and increased the transit trade between the neutrals (Müller 2004, Chapter 7). Although there have been studies on the trade behaviour of some of the neutral states, including the United States, the

\footnotetext{
${ }^{8}$ On the concept of small states in general, see Joenniemi (1998, pp. 61-62).

${ }^{9}$ On definitions of neutrality, as well as small state challenges, see Karsh (1988) and Ackerman (1983, pp. 372-390). On the American interpretations of neutrality and its implications in this time period, see especially Bukovansky (2003, pp. 209-243). Obviously many nations have changed their status from neutral to active belligerent during conflicts, for example the United States during this particular period.

${ }_{10}^{10}$ For an innovative look at the Napoleonic power politics and alliances, see Rosecrance and Lo (1996, pp. 479-500). For a classic account on the Continental System, see Heckscher (1922).
} 
networks between the neutrals and the even the great powers have not yet been studied adequately ${ }^{11}$.

Ultimately, it is completely natural to focus most of the attention in the scholarship to the analysis of the great powers, such as Great Britain and France. After all, it is quite staggering to conceptualise the evolution of an empire such as Great Britain, from its humble beginnings in the $16^{\text {th }}$ century along with the building of the navy and its first major victory against the Spanish Armada to the multicultural, industrialised empire that ruled the world in the $19^{\text {th }}$ century ${ }^{12}$. Moreover, the desire to understand the desperate, global conflict for supremacy from the 1790s to 1815 and Britain's role in this process is again quite understandable (see, for example, Bell 2007) ${ }^{13}$. Or the focus on the naval battles and strategies of these wars, including the building and development of the great fleets, seems quite logical and worthy of intense scholarship ${ }^{14}$. Yet, the intense nature of these rivalries and the total wars between the great powers, in fact, also explain why they had to rely on alliances and often lesser powers to complement their war efforts. Therefore, even a great power like Great Britain had to tolerate the activities of the neutral and/or weaker states, increasing their importance at least temporarily, sometimes to the detriment of their own war efforts.

\section{OVERALL TRENDS IN THE PORTUGUESE EXTERNAL TRADE}

How did Portugal get dragged into these conflicts? The emergence of open conflict between France and England during this period, namely the campaign of Rossilhão (1793-1795), instigated an alliance of England with Spain and Portugal against France, two very different alliances in total. Although France had a superior population, Britain was wealthier, had a more developed economy and ruled the overseas trade with its feared naval power.

Because Britain was in command of the seas, British strategy hinged on harming France's economy, to prevent any French merchant ship from reaching continental ports. The French in turn, ruling the land, tried to prevent British ships from entering those same ports. However, this strategy also affected the neutral nations, who could no longer receive goods that had to pass the blockade imposed by the British navy. As a consequence, and owing to diplomatic pressure from Napoleon, Russia, Sweden and Denmark, in 1800,

11 See the studies listed in Müller (2004). On Denmark, see also Ruppenthal (1943, pp. 7-23). On American trade history and the impact of the blockades, see Keene (1978, pp. 681-700) and Hickey (1981, pp. 517-538).

12 The literature on the great empires is massive and cannot be adequately summarised here. Some of it is discussed in an interesting theoretical article about how and why such empires have come about: Turchin (2008, pp. 191-217).

13 On the debt burden incurred by Great Britain, reaching at its height over 300 per of GDP, see Ferguson (2001).

${ }_{14}$ On the history of the British naval fleet, see especially Kennedy (1998). 
formed the League of Armed Neutrality and forced the British navy out of the Baltic ports and German states ${ }^{15}$.

After many confrontations, the British won the battle of Copenhagen. The Danes surrendered and peace was established in May, 1801, followed by Sweden and Russia. Nevertheless, the broader conflict had not ended. Britain and France were still at war because the British wanted to help the Turks to expel the French from Egypt. Finally, the French retired their army in June of the same year. At this point, both parts were exhausted, and a peace treaty was signed in Amiens, in March $1802^{16}$.

But hostilities between Britain and France renewed shortly, on May 1803. Even though Napoleon declared France an empire on May 18, 1804 and crowned himself as the Emperor, he did not dare to try recovering the colonies lost outside Europe because of the British naval superiority, which continued to disrupt France's extra-continental trade. Britain also had the greatest industrial capacity in Europe, which contributed to its mastery of the seas, allowing it to build up a considerable economic strength through trade and to import raw materials from her colonies. Moreover, Britain's goal was to make sure that France would never control Europe, while the French government thought it was possible to isolate Britain from the continent. Thus, the two nations went on trying to defeat each other. On the one hand, Napoleon could never defeat Britain at sea; on the other, Britain could only mount a serious challenge to France by gathering coalitions. The War of the Third Coalition intensified the ongoing conflict, during which the Battle of Trafalgar in October 1805 reaffirmed the British naval supremacy. But it was not until the Battle of Waterloo, on June 18, 1815, that the Seventh Coalition, under the command of the Duke of Wellington, was able to defeat the Imperial French Army for good, putting an end to Napoleon's rule as Emperor of France and restoring Louis XVIII to the French throne.

Spain, a reluctant ally of France at best, became the first victim of Napoleon in the peninsula. In 1808, he installed his own brother on the Spanish throne after overthrowing the existing government. This thrust the country into chaos and enduring conflict. Thus, the war destabilised not only Portugal, but also Spain. The central authority, in essence, collapsed in Spain during the main thrust of this conflict, from 1808 onwards. Moreover, it was the military forces, often forming local juntas that took over governance at this time, militarising the Spanish society. Furthermore, the military itself was divided into countless quasi-independent units that ruled over their regional domains ${ }^{17}$. Spain's great power status had already been eroding for some time before this war. In particular, its trade links with the colonies had been weakened

\footnotetext{
15 See especially Kennedy (1998) for further discussion.

16 On the negotiations and the breakdown of peace afterwards, see Grainger (2004).

17 On the military's role and fragmentation, see Esdaile (1988). On Napoleon's war in Spain, see, for example, Gates (2002).
} 
significantly. Although Spain was not necessarily in decline as an empire, it certainly was not the same entity as the one described brilliantly by Henry Kamen for the earlier centuries (Esdaile 2003, pp. 9-10; Kamen 2003).

Bearing in mind the close relation and an old alliance between the Portuguese and British Empires, as well as the geographic and strategic position of continental Portugal, which made it a natural prey for the expanding French empire, it is quite natural to analyse the extent of the Portuguese involvement in the conflict and the overall trade impacts. The Peninsular War involved three French invasions of Portugal (1807-1808; 1809; 1810-1811) and, together with the Spanish War of Independence from 1809 until 1814, generated deep instability in the Iberian Peninsula. Since the transmigration of the Portuguese Regent, Prince D. João, and the Royal Court to Brazil in November 1807, Portugal's army had been helped and commanded by English forces, the Peninsular Army, and the invaders were eventually defeated. This help came mainly because of the Portuguese refusal to accept the continental blockade imposed by the French Empire in 1806. The Iberian Peninsula was devastated during this period, suffering massive deaths, pillage, and many fields were burned in order to prevent the advance of the enemy army. One irrefutable reality of this situation was the tremendous lack of cereals to feed the population, not to mention the Peninsular Army.

As a consequence of the close relations between Portuguese and British Empires, already established as an ancient alliance and strengthened during the early years of the $19^{\text {th }}$ century, England was both the main supplier and client of the Portuguese market. In the period from 1808 to 1813, when some external markets such as Holland, Prussia, France, Denmark and Hamburg ceased their trade relations with the Portuguese (the latter three from 1809 onwards), the English, American and Spanish merchants pursued this trade (Moreira 2005: 14). Although distant, the American market took on a key position in terms of imports during the Peninsular War, a development that deserves to be highlighted and analysed further ${ }^{18}$.

As Leos Müller has shown, American shipping increased dramatically during the Revolutionary and Napoleonic conflicts, with a 300 per cent increase in capacity. American shipowners focused heavily on export trade, which meant that they had to find suitable return cargoes. Moreover, as the Napoleonic conquests continued, there were fewer places to do business with in Europe. Therefore, the Nordic markets, Sweden in particular since it was not conquered, formed important destinations for the Americans (Müller 2004, Chapter 7). Similarly, the Portuguese trade with the Nordic countries increased substantially during the war years, although there were some years during which trade was also curtailed. Trade with the other neutrals helped circumvent wartime regulations and shifting alliances, and formed important niche markets for countries such as Portugal and the United States.

18 On the trade patterns before 1770, see Fisher (1963, pp. 219-233). 
In order to analyse the flow of trade between the United States and Portugal, we divided the analysis of the trade into five periods in order to trace the evolution. The years at the close of the $18^{\text {th }}$ century, the first period, were connected to the early $19^{\text {th }}$ century with the opening of the Brazilian ports to the international trade. The third period encompassed the opening of the Brazilian ports until the end of the French invasions in Portugal. The years 1812-1814 were distinguished by the ongoing French invasions in Spain and the war between England and the United States. The subsequent phase encompassed the years after the Peninsular war until the end of that decade. The focal point of the last time period was the third decade of $19^{\text {th }}$ century.

What did the overall trends in the trade look like? On the basis of Cristina Moreira's research, it seems that the big suppliers of the Portuguese imports represented more than 89 per cent of Portuguese imports from 1796 to $1831^{19}$. Table 1 displays the importance of American exports to Portugal, that is, whether the United States was among the top eight suppliers of goods to Portugal. It is surprising that, from 1808 to 1813 , during the Continental blockade and eventually the War of 1812, the United States was not only the second-most important importer, but also that Portuguese imports from the United States reached their highest value (6,297 contos, 28.5 per cent) during this period, which was nearly six times higher than the average for the previous period $^{20}$.

What specific demand elements drove those significant imports during that period? Or, respectively, why would Portugal be willing or be able to trade so much with a country that was not on particularly good terms (or even at war for some of the period) with its main ally, Great Britain, during a period in which both Britain and France were trying to control trade flows? Before we go further, we need to examine the structure of the demand for U.S. products. From a detailed analysis of Portuguese imports from the United States by product, the main conclusion to be drawn is that during the Peninsular War the United States was a particularly important supplier of cereals, mainly flour, corn, wheat and rice, all commodities that were used to support the British troops and the war effort. Imports became even more important when compared with the role of Portuguese exports to the United States in the same period.

In the context of the bicentennial commemorations of the French invasions, it is worth noting that during the Peninsular War the importance of Portuguese imports from the United States grew significantly because of the

19 This research focuses on analysing Balanças Gerais do Comércio do Reyno de Portugal com os seus Domínios Ultramarinos e Nações Estrangeiras, which provides continual series from 1796 to 1831 . Until 1796, we only have Balanças Gerais do Comércio do Reyno de Portugal com os seus Domínios Ultramarinos e Nações Estrangeira for certain years, that is, 1776, 1777, 1783, 1787 y 1789, whereas for the period after the first half of the century Portugal produced only two Balanças de Comércio: the 1843 and 1848 editions. See Moreira (2005) for further discussion.

${ }^{20}$ Calculated from the same sources as those listed under Table 1. 
TABLE 1

IMPORTANCE OF THE AMERICAN MARKET IN TERMS OF VALUE AND ORIGINS OF PORTUGUESE IMPORTS

\begin{tabular}{|c|c|c|c|}
\hline \multirow[b]{2}{*}{ Year } & \multirow[b]{2}{*}{$\begin{array}{c}\text { Portuguese import } \\
\text { values (contos de réis) }\end{array}$} & \multicolumn{2}{|c|}{ USA } \\
\hline & & Position & $\begin{array}{c}\text { Percentage of } \\
\text { Portuguese imports }\end{array}$ \\
\hline $1796-1800$ & 16,333 & $\begin{array}{l}\text { Not included among the } \\
\text { eight main markets of } \\
\text { origin }\end{array}$ & \\
\hline $1801-1807$ & 17,169 & $6^{\text {th }}$ & 6.9 \\
\hline $1808-1811$ & 16,833 & $2^{\text {nd }}$ & 26.9 \\
\hline $1812-1814$ & 29,347 & $2^{\text {nd }}$ & 22.8 \\
\hline $1815-1820$ & 17,619 & $6^{\text {th }}$ & 4.3 \\
\hline $1821-1831$ & $12,403^{\text {(a) }}$ & $\begin{array}{l}\text { Not included among the } \\
\text { eight main markets of } \\
\text { origin }\end{array}$ & \\
\hline
\end{tabular}

Sources: This information has been collated from Portugal's Balance of Trade with Foreign Nations and Portuguese Colonies', Portugal's Balance of Trade with the U.S. Arquivo Histórico do Rio de Janeiro, Balança Geral do Commercio do Reyno de Portugal com as Nações Estrangeiras de 1798 e 1808 (Portugal's Balance of Trade with Foreign Nations in 1798 and 1808) Contadoria da Superintendência Geral dos Contrabandos e Descaminhos dos Reais Direitos. Instituto Nacional de Estatística, Balanças Gerais do Comércio do Reyno de Portugal com os seus Domínios Ultramarinos e Nações Estrangeiras de 1796-1797, 1799-1807, 1809-1831 (Portugal's Balance of Trade with Foreign Nations and Portuguese Colonies 17961797, 1799-1807, 1809-1831), Contadoria da Superintendência Geral.

(a) 10,782 not including the Brazilian market, as registered in the external trade balance from the year 1827. Although the value in the table referring to years 1821-1831 includes the Brazilian trade with Portugal from 1826 due to the Rio de Janeiro Treaty on August 29, 1825, in which Portugal recognized the independence of Brazil.

demand for cereals. Simultaneously, the highest Portuguese exports to the United States coincide, in 1812-1814, with the highest import totals, although the annual average was only 834 contos (6.6 per cent of all Portuguese exports, United States being its fifth biggest customer). Curiously, the highest export totals were reached in 1812 with 1,941 contos (see Table 2 for details).

As seen in Figures 1 and 2, in terms of the development of Portuguese trade relations with the United States during this turbulent period, imports were mostly higher than exports during the most relevant trade years (until 1820), with the exception of the years 1799, 1800, 1805 and 1815.

Although the apparent patterns revealed by the data tables and figures displayed so far suggest certain conclusions, it is not enough to simply «eyeball» the data to find conclusive trends and patterns. What about the Portuguese external trade time series, both exports and imports, themselves, do they reveal anything about the importance and timing of the changes in the trading patterns? Does the analysis of the series support the earlier 
TABLE 2

IMPORTANCE OF U.S. MARKET IN TERMS OF VALUE AND DESTINATION OF PORTUGUESE EXPORTS

\begin{tabular}{|l|c|c|c|}
\hline \multirow{2}{*}{ Year } & \multirow{2}{*}{$\begin{array}{c}|c| \\
\text { Portuguese export values } \\
\text { (contos de réis) }\end{array}$} & Position & $\begin{array}{c}\text { Percentage of Portuguese } \\
\text { exports }\end{array}$ \\
\cline { 3 - 4 } $1796-1800$ & 16,253 & $5^{\text {th }}$ & 2.9 \\
$1801-1807$ & 22,287 & $7^{\text {th }}$ & 2.3 \\
$1808-1811$ & 8,776 & $5^{\text {th }}$ & 3.5 \\
$1812-1814$ & 12,652 & $5^{\text {th }}$ & 6.6 \\
$1815-1820$ & 15,221 & $6^{\text {th }}$ & 2.9 \\
$1821-1831$ & $9,552^{\text {(a) }}$ & $8^{\text {th }}$ & 2.4 \\
\hline
\end{tabular}

Sources: This information has been collated from Portugal's Balance of Trade with Foreign Nations and Portuguese Colonies', Portugal's Balance of Trade with the U.S. Arquivo Histórico do Rio de Janeiro, Balança Geral do Commercio do Reyno de Portugal com as Nações Estrangeiras de 1798 e de 1808 (Portugal's Balance of Trade with Foreign Nations in 1798 and 1808) Contadoria da Superintendência Geral dos Contrabandos e Descaminhos dos Reais Direitos. Instituto Nacional de Estatística, Balanças Gerais do Comércio do Reyno de Portugal com os seus Domínios Ultramarinos e Nações Estrangeiras de 1796-1797, 1799-1807, 1809-1831 (Portugal's Balance of Trade with Foreign Nations and Portuguese Colonies 17961797, 1799-1807, 1809-1831), Contadoria da Superintendência Geral.

(a) 8,223 not including the Brazilian market, as registered in the external trade balance from the year 1827, that is, Portuguese Exports to the United States, 2.8 per cent of its total value. Although the value in the table referring to years 1821-1831 included the Brazilian trade with Portugal from 1826 due to the Rio de Janeiro Treaty on August 29, 1825, in which Portugal recognised the independence of Brazil.

observations about the changing nature of trade during the blockade and hostilities between Britain and the United States. Thus, we decided to work the data further to test the structural qualities of Portuguese exports to the United States; Portuguese imports to the United States; and an index of trade balance (exports/imports $\times 100$ ) for the period $1796-1831^{21}$. The main purpose of this exercise is to pinpoint the exact years during which the trade patterns changed, to compare those findings with the other quantitative and qualitative analyses. To make sure that the unit roots would not distort the results of the structural tests, we performed Augmented Dickey-Fuller and Phillips-Perron tests on the series. The null of a unit root was rejected for all three series. Then we decided to use the Quandt-Andrews Breakpoint Test to determine whether there were one or more unknown structural breakpoints in the time series. The Quandt-Andrews test applies Chow Breakpoint Tests at every observation between two dates to test against the null hypothesis of no breakpoints. From each individual Chow Breakpoint Test, two statistics

21 For a similar approach, that is, to determine the structural qualities of time series to counterbalance the empirical, historical story, see, for example, Meisel and Barón (2010). 
FIGURE 1

PORTUGUESE EXPORTS TO AND IMPORTS FROM THE UNITED STATES, 1796-1831

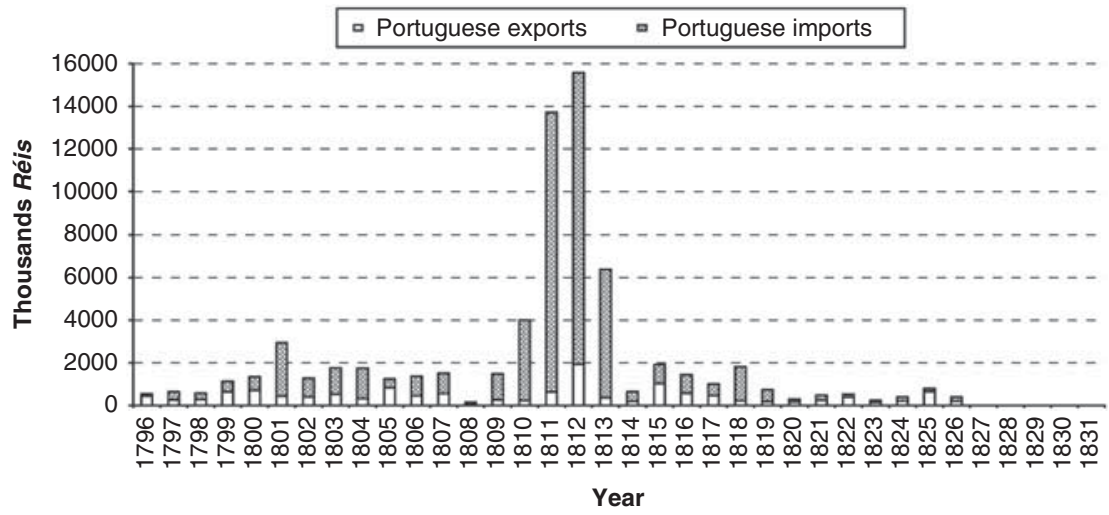

Sources: 'Portugal's Balance of Trade with Foreign Nations and Portuguese Colonies', Portugal's Balance of Trade with the United States.

FIGURE 2

RATIO OF PORTUGUESE EXPORTS AND IMPORTS WITH THE UNITED STATES AND THE RATIO OF TOTAL PORTUGUESE EXPORTS AND IMPORTS,

1796-1831

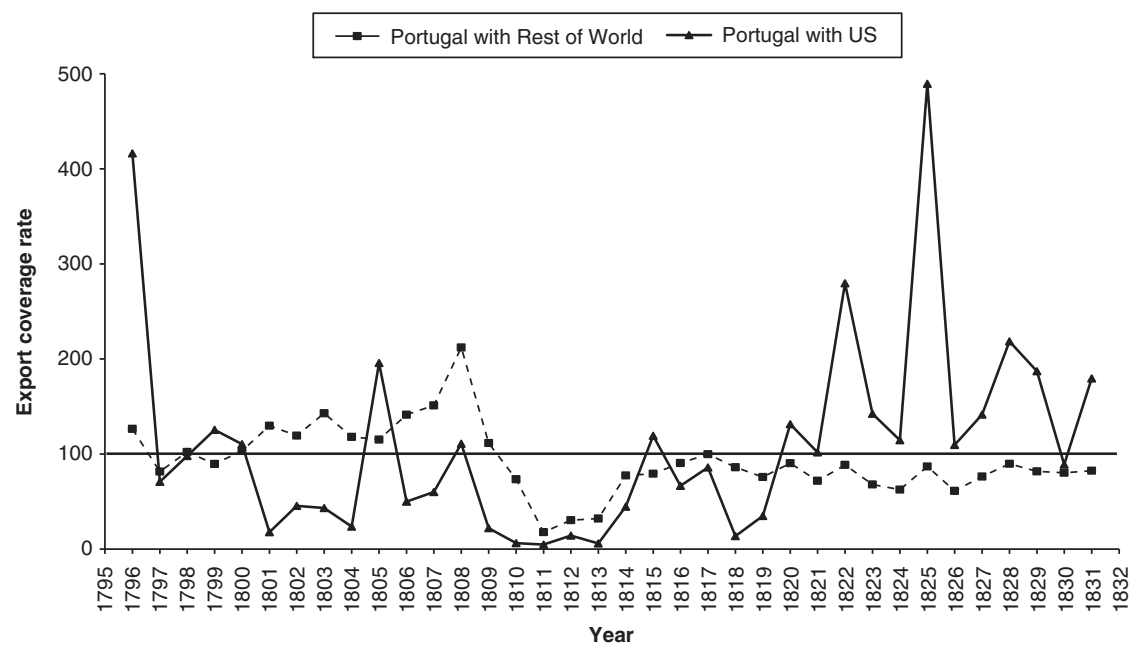

Sources: Idem. 
were retained, the Likelihood Ratio $F$-statistic and the Wald $F$-statistic. We used the Likelihood Ratio F-statistic, which is based on the comparison of the restricted and unrestricted sums of squared residuals. Moreover, we used a simple autoregressive model in which: $y=a+b y(t-1)+$ error term, with each of the three series in turn as the dependent variable.

As seen in Table 3, both the Portuguese imports and the index of trade balance seemed to contain breakpoints. For the imports in particular, the break occurred in the middle of the war between Britain and the United States, which is in line with our initial observations. However, we need to look deeper into the structural qualities of these series, to pinpoint the effects of the disturbances in them over time.

We first looked at the behaviour of recursive residuals (which essentially calculates a one-step forecast error) for the three series, and then the $N$-step probability (which carries out a sequence of Chow Forecast tests and residuals) tests. The results can be seen in Figure 3. For the Portuguese exports, the War of 1812 was a major shock, although the adjustment was fairly quick. The same applies to the imports as well, although the shock seems to have persisted longer. Moreover, the relationship between exports and imports was structurally fairly sound until the 1820 s, significantly after the war years. These results underline our main argument - the Napoleonic Wars altered the structure and context of Portugal's foreign trade. Most likely, however, the impact was fairly short lived. As we have already claimed, this period of conflicts opened up new opportunities for weaker nations like Portugal, giving them temporarily broader leverage in their trade relations, owing to high demand for certain products. The networks cultivated during the wartime, and especially during periods of very high demand like 1806-1813, would not last into the post-war period. Next, we will first take a closer look at the Portuguese imports and then the exports.

\subsection{Portuguese Imports from the United States}

What about more detailed trends in the imports? Or the types of products imported? From 1796 to 1831, cereals were predominantly the most important U.S. products imported by the Portuguese, representing 68-95 per cent of total Portuguese imports (see Table 4) ${ }^{22}$. Furthermore, Portuguese imports from the United States, during the entire period 1796-1831, achieved the highest values during the key years of the Napoleonic conflicts, identifying a greater Portuguese demand for U.S. products.

The main cereals were flour, corn, wheat and rice, as shown in Table 4. The United States supplied the crucial basic cereals for human survival

${ }^{22}$ Except for 1796 (staves comprising 66.0 per cent) and two other years, 1814 and 1820, which include different products that represented less than 10 per cent of the total imports, with the exception of butter (14.5 per cent) in 1814 and fish oil (16.1 per cent) in 1820. 
TABLE 3

STATISTICAL QUALITIES AND BREAKPOINTS FOR PORTUGUESE EXPORTS (POREXP) AND IMPORTS (PORIMP) TO THE UNITED STATES, AND INDEX OF TRADE BALANCE (PORBAL), 1796-1831

\begin{tabular}{|l|c|c|c|}
\hline & POREXP & PORIMP & PORBAL \\
\hline Mean & 410,733 & $1,510,390$ & 110.3 \\
Max. & 309,114 & 473,899 & 93.5 \\
Min. & $1,940,511$ & $13,627,719$ & 489.3 \\
Coefficient of Variation & 665,531 & 74,236 & 4.8 \\
$N$ & 0.84 & 2.08 & 0.97 \\
Quandt-Andrews Breakpoint Year $(P$-value of & 1818 & 36 & 36 \\
Likelihood Ratio $F$-statistic in parenthesis) & $(0.85)$ & $(0.05)$ & $(0.03)$ \\
\hline
\end{tabular}

Sources: Same as in the data tables included in this article. Exports and imports expressed in thousands.

FIGURE 3

RECURSIVE RESIDUALS (FIRST ROW) AND N-STEP PROBABILITIES OF STRUCTURAL DISTURBANCES FOR THE THREE TIME SERIES
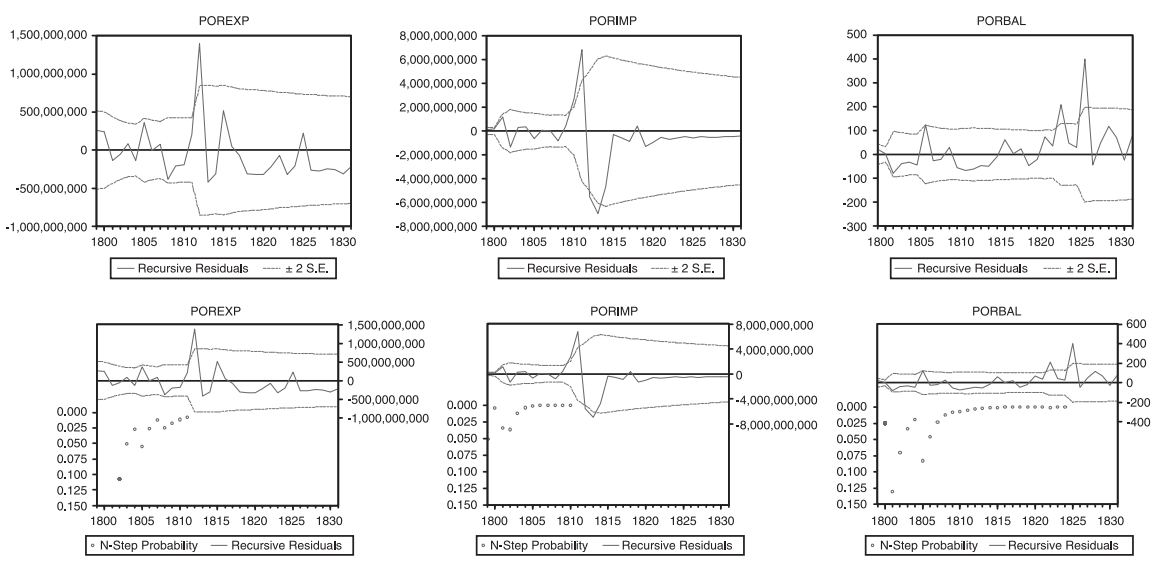

Sources: See previous tables.

during this troubled period, but not only for the civilians. These products were even more crucial for the needs of the Luso-British army, which fought the French on the Portuguese and Spanish soil during the Peninsular War. Flour was consistently the most important cereal supplied, with the value increasing approximately fourfold between 1812 and 1814 when compared to 1801-1807. Corn was the second major product supplied, and its value 
TABLE 4

MAIN U.S. PRODUCTS IMPORTED BY PORTUGAL, 1796-1820 (PER CENT)

\begin{tabular}{|l|c|r|r|r|r|}
\hline Year & Percentage of total imports & Flour & Corn & Wheat & Rice \\
\hline 1796 & 14.0 & 3.3 & 96.7 & 0.0 & 0.0 \\
1797 & 77.0 & 24.3 & 8.0 & 1.7 & 65.9 \\
1798 & 78.7 & 9.1 & 42.3 & 7.4 & 41.1 \\
1799 & 78.5 & 4.3 & 71.5 & 6.6 & 17.6 \\
1800 & 73.4 & 19.9 & 71.4 & 0.0 & 8.7 \\
1801 & 95.2 & 14.4 & 23.2 & 0.3 & 0.5 \\
1802 & 86.1 & 76.0 & 43.5 & 3.2 & 5.5 \\
1803 & 96.1 & 47.8 & 27.7 & 24.9 & 1.3 \\
1804 & 90.0 & 46.1 & 35.4 & 13.4 & 0.9 \\
1805 & 69.1 & 50.3 & 26.6 & 19.9 & 0.0 \\
1806 & 87.7 & 53.5 & 14.4 & 6.1 & 0.0 \\
1807 & 93.9 & 79.5 & 17.2 & 10.2 & 0.0 \\
1808 & 94.8 & 72.6 & 0.0 & 31.0 & 0.0 \\
1809 & 74.6 & 63.3 & 13.4 & 6.3 & 11.2 \\
1810 & 68.0 & 69.0 & 24.2 & 4.3 & 13.9 \\
1811 & 82.7 & 69.2 & 24.7 & 11.1 & 8.0 \\
1812 & 95.4 & 57.6 & 19.9 & 4.8 & 5.9 \\
1813 & 91.0 & 56.2 & 15.8 & 5.2 & 17.6 \\
1814 & 40.3 & 69.4 & 0.0 & 16.6 & 7.6 \\
1815 & 90.8 & 61.4 & 39.4 & 4.6 & 30.6 \\
1816 & 85.8 & 62.8 & 70.8 & 7.1 & 8.7 \\
1817 & 79.0 & 75.8 & 10.4 & 1.4 & 0.0 \\
1818 & 91.3 & 25.4 & 74.7 & 11.3 & 0.0 \\
1819 & 86.3 & 38.8 & 44.7 & 2.8 \\
1820 & 19.8 & 0.0 & 0.0 & 2.4 \\
\hline
\end{tabular}

Sources: 'Portugal's Balance of Trade with Foreign Nations and Portuguese Colonies', Portugal's Balance of Trade with the United States. In 1814, 19 per cent and 16 per cent, respectively, of American dyes and assortments of meats were imported by Portugal.

increased massively during this period. Wheat and rice also contributed to the growth of the imports of cereals during the Peninsular War.

Focusing on annual imports from the United States in the period between 1796 and 1831, and bearing in mind that in the decade of 1821-1831 imports were much smaller by comparison, we can discern a much more precise picture of the dimensions of the yearly demand for cereals (Table 5). 
TABLE 5

PORTUGUESE IMPORTS OF CEREALS FROM THE UNITED STATES, 1796-1831 (UNIT: CONTOS DE RÉIS)

\begin{tabular}{|l|c|r|r|r|r|r|}
\hline Year & Percentage of total imports & Total & Flour & Corn & Wheat & Rice \\
\hline $1796-1800$ & 64.3 & 279 & 40 & 150 & 10 & 79 \\
$1801-1807$ & 88.3 & 1,080 & 684 & 286 & 99 & 11 \\
$1808-1811$ & 80.1 & 3,589 & 2,057 & 854 & 347 & 331 \\
$1812-1814$ & 75.6 & 6,222 & 4,177 & 1,149 & 313 & 584 \\
$1815-1820$ & 75.5 & 650 & 161 & 357 & 78 & 53 \\
$1821-1831$ & 11.0 & 19 & 4 & 2 & 5 & 8 \\
\hline
\end{tabular}

Sources: 'Portugal's Balance of Trade with Foreign Nations and Portuguese Colonies', Portugal's Balance of Trade with the United States.

Note: The period totals may not correspond to the sum of the individual categories given the rounding of the figures.

As we have already highlighted, flour accounted for most of the Portuguese imports of cereals from the United States, accounting for 75.6 per cent of the total cereal imports in 1812-1814, mainly because of the increase in the quantities demanded by the Portuguese population and British troops. This was also a period during which Portugal ceased commercial relationships with certain markets. Lisbon was the main entrance port for the American cereals. The major contributions to the Portuguese demand for American cereals were based on flour (1810-1813), corn (1811) and wheat (1811-1812), the latter two in smaller amounts (see Table 6, especially the highlighted sections).

As Table 7 shows, the United States was the main origin of flour for Portugal, not only during the period of major demand but for the entire period. Available data depict 1812 as the year during which the peak value for flour was attained mainly because of quantities, as the price of 1,100 réis per alqueire was not significantly different from the prices for the years 1810, 1811 and 1813 (respectively 978, 973 and 960 réis per alqueire). The increased demand for American corn in 1811 and 1813 represented 95 and 97 per cent, respectively, of all corn imported and also reveals United Staes as the former main supplier.

American wheat increased in importance among the imported cereals, particularly in 1811 and 1812, corresponding to a contraction in Spanish wheat imports because of the Peninsular War. The United States was the second-most important supplier, representing between 26 and 28 per cent of the total Portuguese wheat imports. During the war, the other main importers of wheat were Great Britain, Spain, Italy and the Berber countries. American rice imports were also imperative during the conflict, with 1813 being the year of the most significant totals, equalling 965 contos, although this was less than the quantities for the other cereals. 
TABLE 6

QUANTITIES OF MAIN PRODUCTS IMPORTED FROM THE UNITED STATES, 1796-1820 (UNIT: ALQUEIRES)

\begin{tabular}{|c|c|c|c|c|}
\hline Year & Total amount of cereals & Flour & Corn & Wheat \\
\hline 1796 & 45,792 & 1,164 & 44,628 & - \\
\hline 1797 & 211,223 & 149,598 & 49,125 & 12,500 \\
\hline 1798 & 334,553 & 51,701 & 240,596 & 42,256 \\
\hline 1799 & 668,927 & 24,012 & 612,435 & 32,480 \\
\hline 1800 & 669,826 & 93,012 & 576,814 & - \\
\hline 1801 & $2,111,254$ & $1,365,596$ & 738,976 & 6,682 \\
\hline 1802 & $1,579,550$ & 552,470 & 985,136 & 41,944 \\
\hline 1803 & $2,580,620$ & $1,003,902$ & $1,055,260$ & 521,458 \\
\hline 1804 & $2,098,063$ & 881,003 & 965,418 & 251,642 \\
\hline 1805 & 444,421 & 182,108 & 187,886 & 74,427 \\
\hline 1806 & $1,278,070$ & 894,702 & 314,314 & 69,054 \\
\hline 1807 & $1,305,178$ & 799,782 & 382,521 & 122,875 \\
\hline 1808 & 76,632 & 52,368 & 0 & 24,264 \\
\hline 1809 & $1,180,766$ & 830,595 & 265,437 & 84,734 \\
\hline 1810 & $2,418,371$ & $1,510,688$ & 784,550 & 123,133 \\
\hline 1811 & $11,874,203$ & $6,248,672$ & $4,484,829$ & $1,140,702$ \\
\hline 1812 & $9,405,856$ & $8,209,788$ & 600,872 & 595,196 \\
\hline 1813 & $5,280,721$ & $3,452,532$ & $1,500,059$ & 328,130 \\
\hline 1814 & 224,017 & 178,974 & 0 & 45,043 \\
\hline 1815 & 977,141 & 275,556 & 651,446 & 50,139 \\
\hline 1816 & $1,279,537$ & 114,360 & $1,088,987$ & 76,190 \\
\hline 1817 & 423,843 & 335,736 & 80,723 & 7,384 \\
\hline 1818 & $2,517,496$ & 0 & $2,264,177$ & 253,319 \\
\hline 1819 & $1,122,889$ & 86,400 & 570,532 & 465,957 \\
\hline 1820 & 40,602 & 40,602 & 0 & 0 \\
\hline
\end{tabular}

The highlighted section in grey shows the most significant period of importation of cereal from the United States.

Sources: 'Portugal's Balance of Trade with Foreign Nations and Portuguese Colonies', Portugal's Balance of Trade with the United States. In 1813 it is not possible to decompose the value of 286 contos of wheat imported from the United States in quantities and price. The unit for cereals is alqueire, although in the case of flour, barricas and barris are also units; these are not listed as they correspond to irrelevant import values.

The relevance of American flour supplies during the Peninsular War, which is evident from the study of the quantitative sources, can be further analysed by cross-referencing them with two important qualitative sources, 
TABLE 7

QUANTITIES OF MOST IMPORTANT IMPORTED FLOUR, 1796-1820 (UNIT: ALQUEIRES)

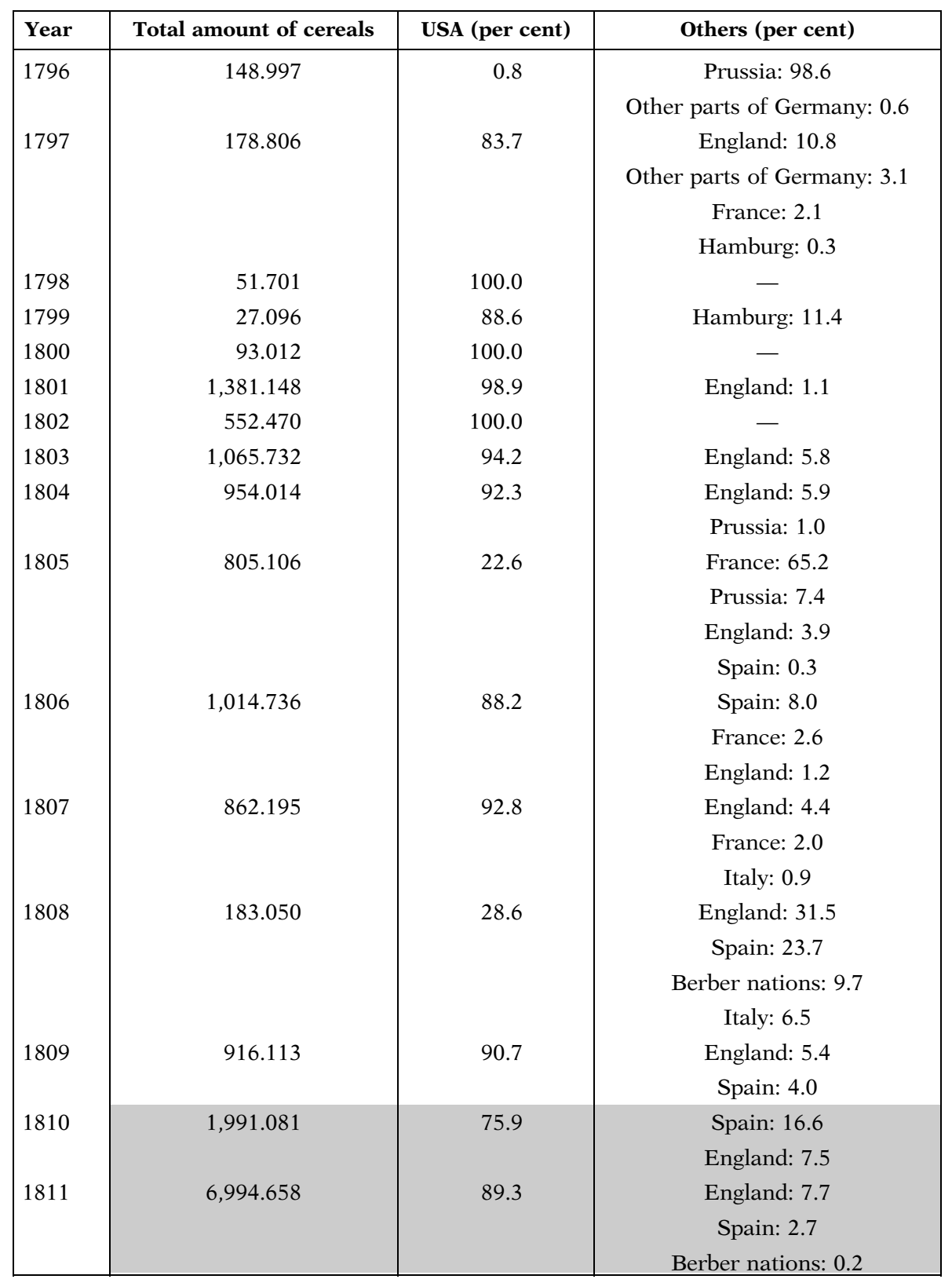


TABLE 7 (Cont.)

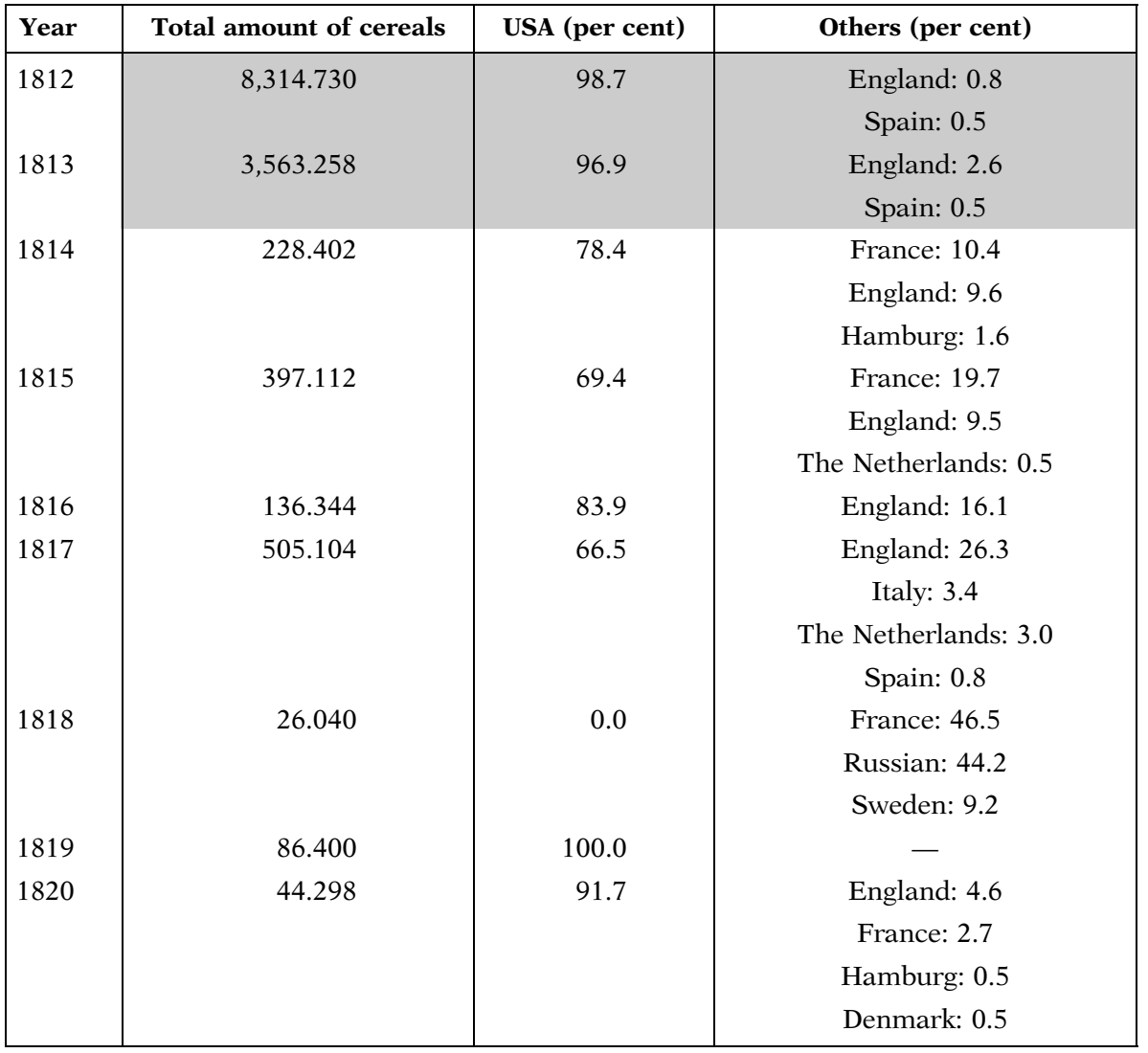

The highlighted section in grey shows the most significant period of importation of flour.

Sources: 'Portugal's Balance of Trade with Foreign Nations and Portuguese Colonies', Portugal's Balance of Trade with the United States. The unit for cereals is alqueire, although in the case of flour, barricas and barris are also used; these are not listed as they correspond to very small import values.

namely consular and military correspondences. As it is clear that Portugal imported flour mostly from the United States, it is quite telling to find references to that product in a $19^{\text {th }}$-century handwritten document ${ }^{23}$, found at Tribunal de Contas, corresponding to the years 1815 and 1816, just after the Paris Treaty had been signed. It shows clearly that the Portuguese army listed "American flour» in its military monthly reports of acquisitions under «General Account of Provisions», Conta Geral de Géneros.

${ }^{23}$ Arquivo Tribunal de Contas (Archives of the Audit Court): ER 5451. 
In fact, cross-checking this reference with the previously presented data, and assuming that «American flour» refers to flour imported from the United States, the quantities acquired by the army corresponded, respectively, to 30 and 56 per cent of the imported flour (see earlier tables) in $1815(83,969$ alqueires) and 1816 (64,140 alqueires).

During the Peninsular War, in letters dated June $20^{24}$, August $8^{25}$ and December 10, $1810^{26}$ from Jozé Rademaker, the Portuguese Consul in Philadelphia $^{27}$, who was persistently requested to ensure that American traders exported flour to Lisbon, explained to the Portuguese Ministry of War and Foreign Affairs that many of those traders did not want to do so, because of the low profits obtained from that trade, after covering their expenses, insurance, freight and taxes ${ }^{28}$. From details contained in a letter dated August 8 of that year, it becomes clear that the price for flour was 8,800 réis/ barrica in Philadelphia, yet it was being sold for 12,800 réis/barrica in Portugal. The only way to persuade the traders, as Jozé Rademaker suggests, was to increase the selling price, or to lower the duty fees on the products they wanted to import from Portugal, namely white wines. However, Rademaker continued to publicise the opportunity to the traders at all ports, inducing further competition, to merchants who wanted to export wheat and flour to Portugal, and he made references to the fact that several ships had left Baltimore bound for Lisbon, and another four from Philadelphia, with several more waiting to leave New York and the Carolinas ${ }^{29}$. Although the Portuguese statistics for each external market do not provide information on the regional provenance of the imported products, the relevance of the Philadelphia and New York ports in this trade was also confirmed by data from a military source ${ }^{30}$, a document dated February 25, 1811, which makes it possible to trace the main origins of that American flour, namely to New York, Philadelphia and Baltimore.

${ }^{24}$ Letter sent in answer to a request to increase wheat and flour exports to Portugal, Instituto dos Arquivos Nacionais Torre do Tombo (Institute of National Archives/Torre do Tombo), Box 62074

25 Idem.

26 Idem.

27 In 1810, the American Consuls in Portugal were: William Jarvie in Lisbon, James L. Cathcart in Madeira, John B. Dabney in the Azores and Henry Hill in San Salvador in Brazil. Document no. 151, Consuls and Commercial Agents, Table Commerce and Navigation 820 in American State Papers - Legislative and Executive Documents of the Congress of the United States. Commerce and Navigation, Vol 1. http://memory.loc.gov/ammem/amlaw/lawhome.html.

${ }^{28}$ Letter from Jozé Rademaker to D. Miguel Pereira Forjaz, Philadelphia, August 8, 1810, on the shipment of flour to Portugal, Instituto dos Arquivos Nacionais Torre do Tombo (Institute of National Archives/Torre do Tombo), Box 62074.

${ }^{29}$ Letter from José Rademaker, dated December 10, 1810, on the shipment of flours to Portugal, Instituto dos Arquivos Nacionais Torre do Tombo (Institute of National Archives/Torre do Tombo), Box 62074.

${ }^{30}$ Arquivo Histórico Militar (Military Historic Archive), PT AHM/DIV/1/24/245/31. Report from José Rademaker to D. Miguel Pereira Forjaz, minister and secretary of state for War Affairs, on food products and list of flour prices in the United States. 
This same source enables us to identify the price of flour in the United States, namely between 9 dollars 75 cents and 10 dollars in New York, 10 dollars and 50 cents in Philadelphia and 9 dollars and 50 cents in Baltimore. For all these examples, this source reinforces the idea of seemingly low profits for traders, as referred to in Rademaker's consular correspondence, as it indicates that the expenses, insurance, freight and taxes amounted to between 3 and 3 dollars 50 cents per barrica, which corresponded approximately to 2,756 réis, when considering an exchange rate of 848 réis per dollar found for $1809^{31}$. By applying this exchange rate to the figures mentioned in Rademaker's letter from 1810, it can be concluded that the profit was initially fairly low, around 1,244 réis/barrica (1 dollar 47 cents/barrica), amounting to 10.8 per cent as the difference between 12,800 réis and 8,800 réis, 4,000 réis, excluding 2,756 réis for insurance, freight and taxes.

Was the Portuguese metropolis the main consumer of the growing external demand for cereal in the period that followed the French invasions in Portugal? Was the U.S. market part of the solution? If that was the case, the Spanish cereal imports should also show a great rise given the geographical proximity and the quality of the Spanish wheat and the disparity of prices between the two countries, considering that the Spanish cereal was cheaper than the Portuguese. Curiously enough, the Portuguese demand for Spanish cereal in the first three decades of the $19^{\text {th }}$ century reached its peak not from 1812 to 1814 , but from 1808 to 1811 . We maintain that this significant rise in the U.S. cereal exports to Portugal between 1812 and 1814 confirms the thesis that the metropolis acted as a support platform to feed its greatest ally during the war between the United States and what was then the British colony of Canada. A state of war between the United States and Britain did not provide a hindrance to the trade, on the contrary.

The consular correspondences for the year of highest American flour imports, which was 1812 (8,209,788 alqueires according to the Portuguese trade balances), make interesting references to specific quantities of this product for that same year. One letter stated that four Portuguese vessels left Philadelphia on July 22, 1812, bound for Oporto, with 2,135 barricas of flour and, on the very next day, another five American vessels left Philadelphia for Lisbon containing 9,800 barricas, and «... much more would go if the fear of being captured by the English did not discourage them... $»^{32}$. Thus, the fear of capture, and loss of profits and assets, by the English naval forces was a

31 Letter dated December 29, 1809, Instituto dos Arquivos Nacionais Torre do Tombo (Institute of National Archives/Torre do Tombo), Box 62077.

32 Letter dated July 23, 1812, on the difficulty of bringing flour to Portugal due to the war with England and what else is suggested about the Portuguese crews, Instituto dos Arquivos Nacionais Torre do Tombo (Institute of National Archives/Torre do Tombo), Box 62074. The War of 1812 was fought between the United States and the United Kingdom of Great Britain and Ireland and its colonies: Upper Canada [Ontario], Lower Canada [Quebec], Newfoundland and Nova Scotia, and Bermuda. 
real possibility. Yet, most of the time, they allowed this trade to take place, even during the actual conflict with the United States, the War of 1812. However, this source makes no reference to the values or prices involved with taking those exports to the Portuguese markets. It is a reasonable conjecture that the profits, and the relative prices received by the importers, in this trade must have risen substantially along with both the risks involved and the heightened demand caused by the conflict ${ }^{33}$.

Unfortunately, in the Portuguese trade statistics, quantities of imported flour are not expressed as barricas, but mainly as alqueires, and there is no convenient conversion factor to be found for these units. There are, however, some records given in barricas and barris ${ }^{34}$, although these referred to transactions with very low values. Curiously, the quantities of barricas of flour referred to in the above-mentioned letter are not accounted for in the Portuguese Trade Balance records. Considering that those quantities only refer to 2 days of vessel movements and that a huge demand for American flour is revealed by several of the letters researched, together with the opportunity to cross-check the quantitative and qualitative sources, it seems plausible that the amount of flour that had been converted to alqueires for the records in 1812 was an error in the records or a manifestation of contraband, or at least remains open to discussion. The latter explanation would certainly fit with the pattern of this type of trade, with large expected profits.

Why did the Portuguese import wheat flour, rather than the grain? A memoir on the trade between Portugal and United States, written by Ignacio Palyart in 1788, states that wheat was one of the most important farming products in the states of New York, New Jersey, Pennsylvania and Delaware, exported mainly to Portugal, Spain and some other Mediterranean ports. France and England only imported wheat when facing a year of really bad harvests and scarce supplies. During the latter half of the 1780s, Portugal imported mainly raw wheat, thereby avoiding manufacturing costs, after a period when imports were preferably of wheat in the form of flour. This change in demand affected Philadelphians so much that in 1786 they overcharged for Portuguese wines, up to 20 per cent more than in other states. However, Portugal could unload goods at other ports as well, which then entered Pennsylvania illegally, thus avoiding those duties. The importance of Philadelphia in the flour trade was heightened by the fact that wartime Great Britain was very dependent on North American markets. For example, Lower Canada was a great producer of wheat, which unfortunately could only be exported by way of the St. Lawrence River, which was frozen most of the year. Therefore, Canada's trade was underdeveloped to the benefit of

33 On the broader trade networks between Southern Europe and North America, see Lydon (1965).

${ }^{34}$ Trade balances were for the years 1813 (2.600 at a price of 11.604 réis/barrica by Setubal), 1816 (2.560 priced 8.200 réis/barrica by Oporto) and 1817 (2.131 for 12.620 réis/barrica by Oporto), 1818 (20.579: 13.210 by Lisbon and 7.069 by Oporto both at 9.890 réis/barrica and 300 by Figueira priced between 6.000 and 9.890 réis/barrica) and finally 1821 (9.609 at 5.000 réis/barrica by Lisbon). 
Philadelphia in particular, as «... Philadelphians monopolised wheat and transformed it into flour in their ports, re-exporting it to Portugal and other kingdoms... ${ }^{35}$. The disruption of agricultural life and destruction of most of the mills because of the Peninsular War may have been the reason for the shift in the Portuguese demand from grain back to flour once again.

To facilitate trade, Portugal wanted to buy American vessels and use them under the Portuguese flag in order to transport flour to Portugal. However, the existing trade treaty between England and Portugal demanded that the owner of the vessel, its captain and one-third of the sailors be under the orders of the Portuguese Prince Regent. This reality prevented many other vessels from taking part in the flour trade, as there were not enough Portuguese sailors in the United States for that purpose. In order to avoid this problem, in 1812, Jozé Rademaker ${ }^{36}$ suggested that the Portuguese should follow the Spanish model in this: Only the owner of the vessel and its captain should have to be Portuguese.

The war that pitted United States and England against one another from 1812 to 1815 - because of, among other reasons, Britain's annoyance with U.S. trade with France and American impressments of British sailors, as well as British support of Indian raids - was accompanied by several attempts by England to put an embargo on U.S. ports, adding many obstacles to international trade. The trade between Portugal and United States was no exception; thus, it faced another challenge, as many of the American traders who operated with English licences under the American flag exporting flour to Spain and Portugal saw their businesses compromised. Again, Jozé Rademaker attempted to persuade several Americans to become naturalised as Portuguese in order to run vessels with the Portuguese flag and using Portuguese passports. The forty-nine passports, which arrived in Philadelphia in 1812, were reported as insufficient. In fact, three vessels with food supplies left New York on September 7, 1812 under such conditions, one heading to Lisbon and two to the island of Fayal in the Azores. Clearly problems with wartime situations could be overcome with fairly practical solutions.

From the various Portuguese sources mentioned above, indubitably the trade relations between Portugal and the United States were mainly anchored by the Portuguese demand for American cereals in 1812-1814. Although the American sources, namely American State Papers, exhibit a lack of annual records of American imports and exports detailed by products for each external market during the period in question, a further study of that source revealed that, from 1808 to 1814, the Portuguese market was also an important destination for American exports, ranking as the second-most

35 Memoir Observação sobre o comércio dos Estados Unidos d'America com Portugal por Ignacio Palyart (Observation on trade between United States and Portugal by Ignacio Palyart) in 1788. Instituto dos Arquivos Nacionais Torre do Tombo (Institute of National Archives/Torre do Tombo), Box 62109.

${ }^{36}$ In a letter dated September 7, 1812, Instituto dos Arquivos Nacionais Torre do Tombo (Institute of National Archives/Torre do Tombo), Box 62074. 
TABLE 8

POSITION OF PORTUGUESE MARKET IN TERMS OF VALUE AND DESTINATION OF U.S. EXPORTS, 1808-1814

\begin{tabular}{|l|c|c|c|}
\hline \multirow{2}{*}{ Year } & American export values & \multicolumn{2}{|c|}{ Portugal } \\
\cline { 3 - 4 } & $22,430,960$ & Position & Percentage of American exports \\
\hline 1808 & $52,203,233$ & $6^{\text {th }}$ & 2.4 \\
1809 & $66,757,970$ & $3^{\text {rd }}$ & 15.9 \\
1810 & $61,316,833$ & $4^{\text {th }}$ & 11.5 \\
1811 & $38,527,236$ & $3^{\text {rd }}$ & 18.7 \\
1812 & $27,855,997$ & $2^{\text {nd }}$ & 24.4 \\
1813 & $6,627,441$ & $2^{\text {nd }}$ & 36.2 \\
1814 & $3^{\text {rd }}$ & 8.5 \\
\hline
\end{tabular}

Sources: This information has been collated from American State Papers - Legislative and Executive Documents of the Congress of the United States. The source does not differentiate exports by products.

important in 1812 and 1813; third in 1809, 1811 and 1814; and fourth in 1810 and sixth in 1808 (see Table 8).

The crucial issue of the supply of American cereals to Portugal shows that, although distant, help from America was essential for the survival of the Portuguese people and the Luso-British army, an indirect but no less important means of support. These economic transactions enabled the survival of the Portuguese people and English troops during the most difficult phases of the Napoleonic conflicts. The expected profits also rose dramatically during the most intense years of the war, only to decline again during peace time.

\subsection{Portuguese Exports to the United States}

Do exports reinforce this story? Research focusing on Portuguese trade statistics reveals that the Portuguese exports to the United States were much less significant compared to the Portuguese imports from the United States. The U.S. demand for goods imported from Portugal focused mainly on wine, Patacas Castelhanas (Spanish silver coins) and salt, as imports of those three products constituted $65-98$ per cent of the total value exported to the United States from 1796 to $1820^{37}$, as shown in Table $9^{38}$.

The highest value of Spanish silver coins exported was reached in 1812, totalling 1,524 contos. Comparatively, in 1805, the total was 581 contos, and

37 The year 1825 was an isolated year among the period 1821-1831, with a relevant value of exports, as mentioned above: 654 contos from which 561 contos corresponded to wool.

${ }^{38}$ This excludes 1814 and 1815 mainly because of the demand for textiles in those years. Although the Portuguese exports to the United States were irrelevant in 1814, in the following year they reached 590 contos -57 per cent of the total exports. 
TABLE 9

MAIN PORTUGUESE PRODUCTS EXPORTED TO THE UNITED STATES, 1796-1820 (PER CENT AND CONTOS)

\begin{tabular}{|c|c|c|c|c|c|c|c|}
\hline \multirow[b]{2}{*}{ Year } & \multirow[b]{2}{*}{$\begin{array}{c}\text { Share of } \\
\text { total exports }\end{array}$} & \multicolumn{2}{|c|}{ Wine } & \multicolumn{2}{|l|}{ Salt } & \multicolumn{2}{|c|}{$\begin{array}{c}\text { Patacas castelhanas, } \\
\text { Spanish silver } \\
\text { coins (1) }\end{array}$} \\
\hline & & $\begin{array}{c}\text { Percentage } \\
\text { of exports }\end{array}$ & Contos & $\begin{array}{c}\text { Percentage } \\
\text { of exports }\end{array}$ & Contos & $\begin{array}{c}\text { Percentage } \\
\text { of exports }\end{array}$ & Contos \\
\hline 1796 & 89.5 & 45.7 & 201.7 & 19.6 & 86.6 & 24.1 & 106.3 \\
\hline 1797 & 84.4 & 48.6 & 129.2 & 27.4 & 72.9 & 8.3 & 22.1 \\
\hline 1798 & 85.4 & 36.8 & 104.3 & 25.3 & 71.8 & 23.3 & 66.1 \\
\hline 1799 & 93.0 & 24.8 & 156.6 & 7.2 & 45.1 & 61.0 & 384.6 \\
\hline 1800 & 94.2 & 20.1 & 141.6 & 8.8 & 62.1 & 65.2 & 459.6 \\
\hline 1801 & 86.9 & 42.4 & 188.4 & 8.7 & 38.8 & 35.8 & 158.7 \\
\hline 1802 & 87.8 & 34.4 & 138.2 & 22.8 & 91.6 & 30.6 & 122.6 \\
\hline 1803 & 88.6 & 16.2 & 85.9 & 15.6 & 82.6 & 56.7 & 300.2 \\
\hline 1804 & 87.9 & 43.6 & 145.8 & 20.2 & 87.7 & 18.2 & 60.8 \\
\hline 1805 & 93.6 & 17.4 & 144.0 & 5.8 & 47.6 & 70.4 & 581.4 \\
\hline 1806 & 89.8 & 42.5 & 194.8 & 12.1 & 55.4 & 35.3 & 161.6 \\
\hline 1807 & 92.8 & 42.1 & 239.7 & 15.6 & 88.7 & 35.1 & 200.2 \\
\hline 1808 & 80.7 & 65.9 & 54.3 & 14.8 & 12.2 & 0.0 & 0.0 \\
\hline 1809 & 77.1 & 49.4 & 132.8 & 27.7 & 74.4 & 0.0 & 0.0 \\
\hline 1810 & 69.3 & 16.5 & 39 & 47.8 & 112.9 & 5.1 & 12.0 \\
\hline 1811 & 72.6 & 8.8 & 55.5 & 37.5 & 236.1 & 26.3 & 165.6 \\
\hline 1812 & 93.9 & 4.6 & 88.7 & 10.8 & 209.9 & 78.5 & $1,523.7$ \\
\hline 1813 & 64.7 & 2.0 & 7.3 & 62.7 & 226.5 & 0.0 & 0.0 \\
\hline 1814 & 3.8 & 1.0 & 2.0 & 2.8 & 5.6 & 0.0 & 0.0 \\
\hline 1815 & 19.0 & 10.3 & 106.4 & 5.7 & 58.9 & 3.0 & 31.2 \\
\hline 1816 & 83.4 & 33.1 & 190.4 & 15.3 & 88.1 & 35.0 & 201.6 \\
\hline 1817 & 97.9 & 10.5 & 48.8 & 6.1 & 28.5 & 81.3 & 378.4 \\
\hline 1818 & 76.9 & 5.0 & 11.0 & 31.7 & 69.5 & 40.2 & 88.2 \\
\hline 1819 & 89.0 & 1.7 & 3.2 & 37.5 & 71.2 & 49.7 & 94.4 \\
\hline 1820 & 96.8 & 41.2 & 68.4 & 39.5 & 65.6 & 16.1 & 26.8 \\
\hline
\end{tabular}

Sources: 'Portugal's Balance of Trade with Foreign Nations and Portuguese Colonies', Portugal's Balance of Trade with the United States.

Note: During the period under analysis, there are several other references to this aggregated product in Portuguese trade balances: From 1798 to 1800; it appears as «Silver as patacas and pesetas» and in 1818 under the designation of "Patacas and onças castelhanas»; from 1801 to 1806 this product was referred to by «Silver as patacas, » and merely by «Patacas» in 1807 and 1820. It is assumed that all were Spanish silver coins. In the year 1810, wool represented 13.7 per cent of exports, the third major exported product. In the years 1808, 1809 and 1813, only salt and wine in the first two cases and salt in 1813 represented more than 10 per cent of Portuguese exports to the United States. In 1815, fabrics (cotton, wool and linen) represented 57 per cent of Portuguese exports to the United States. In the previous year, fabrics were also the most important product, together with tea, but the values were irrelevant. See Moreira (2007a, pp. 95-103) for further discussion about Portuguese wool exports to the United States. 
in 1800 it reached 460 contos. We can conclude that the Portuguese exports to the United States for most of the period under study were quite modest, with the exception of the Spanish silver coins, specifically in the first year of the War of 1812. The Portuguese trade statistics indicate six origins for the exported products: Portuguese Kingdom, Portuguese Islands, Brazil, Africa, Asia and re-exports. Although the origin of wine and salt was the Kingdom, Spanish silver coins were recorded as re-exported. The re-exported Spanish silver coins were not a means of payment but a product, according to Portuguese trade balance sources, namely those for the year $1817^{39}$. Imports of Spanish silver coins were clearly insufficient to meet the external demand.

Therefore, this product had either joined the large stream of contraband imports as it was not recorded among the imports, or the recorded origin should be the United Kingdom. However, at that time, neither Portugal nor its colonies were extracting silver. The Spanish silver was part of the illegal trade, which can be seen in the fact that tobacco smugglers in Portugal, namely in Campo Maior, exported tobacco to Spain in exchange for illegally introduced Spanish silver coins ${ }^{40}$.

The Alvará ${ }^{41}$ of October 17, 1808 issued by the Portuguese Regent Prince $^{42}$ makes it clear that there were Spanish silver coins circulating in Portugal, as it is mentioned that the English Army in Portugal was effectively paid with them ${ }^{43}$. Owing to the great increase in the quantity of silver coins in circulation, the Portuguese Prince Regent had to recognise the importance of the pataca, and he assigned the value of 800 réis to each pataca. It is obvious that patacas used as army payments could not be expected to be found in the trade balance data.

It seems that both the quantitative and qualitative evidence, based on Portugal's export and import data, point in the same direction. In the context of this era of global war, Portugal, a small player in the international arena and an old British ally, built a bridge between two important economic actors, the United States and Great Britain, purely out of need on the British side and profit opportunities on the U.S. side. Portugal relied on American cereal in order to feed the Portuguese and British armies operating in Portugal and, on the other hand, supplied the United States with silver that basically originated from British payments to that common army. This increase in trade

39 Balança Geral do Commercio do Reyno de Portugal com os seus Dominios e As Nações Estrangeiras Em o Anno de 1817, Portugal's Trade Balance with Foreign Nations and Portuguese colonies in 1817.

40 Balança Geral do Commercio do Reyno de Portugal com os seus Dominios e As Nações Estrangeiras Em o Anno de 1818, Portugal's Trade Balance with Foreign Nations and Portuguese colonies in 1818 .

${ }^{41}$ Alvará was a document issued by the Prince Regent.

42 Instituto dos Arquivos Nacionais Torre do Tombo (Institute of National Archives/Torre do Tombo), Box 62150.

43 See Moreira (2007b). The military expenditures during the Peninsular War had the English government's financial support; the values are expressed in réis and pounds sterling. 
began with the imposition of the Continental blockade. The War of 1812 simply expanded this trade even further, raising relative prices and increasing the attractiveness of illicit modes of trade. Nonetheless, most of those opportunities were relatively short-lived, as the great powers were no longer so dependent on the trade networks and crucial commodities of the neutral or small (or weaker) nations during peace time.

\section{CONCLUSION}

The coming of modernity, industrial age and ultimately the hegemony of Great Britain emerged out of series of massive conflicts, thrusting Europe and its colonies into the first real-world war from the early 1790s to 1815 . These conflicts forced countries to choose sides and strained old alliances. Related to these processes, a new political and economic, albeit weak, power entered into the fray during this period of transition, from the 1790s to 1815 , the United States. In this article, we wanted to re-examine the role played by smaller and/or weaker (sometimes also neutral) powers, which would apply to both Portugal and the United States, and the importance of trade opportunities during a time of war. On the basis of new sources and data on Portuguese-American trade, we wished to analyse why and to what extent it was possible for Portugal to trade with the United States, despite its apparent animosity of Great Britain, Portugal's oldest ally.

Portugal suffered three French invasions during Napoleon's rule, and, as it did not adhere to the Continental blockade, it experienced trade restrictions with several of its former suppliers. Thus, the Peninsular War caused severe disruptions of agricultural production in Portugal, and the United States, despite its strained relations with an ally of Portugal, Great Britain, became a key supplier for the Portuguese civilians and the military forces residing in the country. By analysing primary sources, it became very clear that the most relevant growth period of U.S. exports to Portugal was 1807-1812. The main products imported from United States during that period were cereals, both as grain and as flour. The sudden increase in the demand for cereals was clearly due to the need to feed both the Portuguese people and the Portuguese and English armies, engaged in fighting the French on Portuguese territory. The threatened position of the peninsula awarded the Portuguese and American entrepreneurs some room to manoeuvre in the international markets, despite considerable British annoyance at American trade practices.

However, after 1812, the war pitting the United States against England brought meagre difficulties for the United States-Portuguese trade, as U.S. shipments with cereals and flour were at times captured by England. Meanwhile, Portugal exported mainly wine, silver in the form of Spanish patacas and salt, although the export values were much lower than the imports during the period of more significant trade. Striking is also the prominent position of 
the Portuguese market as a U.S. client market, during the Peninsular War, reaching more than a 10 per cent share of all U.S. exports from 1809 until 1813. Obviously, then, the British Navy was not a massive obstacle for this trade, especially as they also benefitted from the inflow of cereals and other goods, and the expected profits were high. Illicit trade also flourished. Business acumen and economic needs trumped the principles of war and diplomacy. However, weak states like Portugal and the United States gained new market opportunities only in the short run - the return to normalcy in the $1820 \mathrm{~s}$ erased many of these gains and networks. The examination of the structural characteristics of the Portuguese trade statistics confirmed this as well: the War of 1812 represented an expansion, albeit most likely a temporary state of affairs, of this trade. The reversal of the political situation after the second defeat of Napoleon and the Congress of Vienna once again changed the external environment for trade. Clearly, even total war was not always bad for trade, at least for Portugal in this instance.

\section{PRIMARY SOURCES}

American State Papers - Legislative and Executive Documents of the Congress of the United States. Commerce and Navigation, vol. I. http://memory. loc.gov/ammem/amlaw/lawhome.html

Arquivo Histórico do Rio de Janeiro, Balança Geral do Commercio do Reyno de Portugal com as Nações Estrangeiras em o anno de 1798 e Balança Geral do Commercio do Reyno de Portugal com as Nações Estrangeiras em o anno de 1808 (Portugal's Balance of Trade with Foreign Nations in 1798 and 1808) Contadoria da Superintendência Geral dos Contrabandos e Descaminhos dos Reais Direitos.

Arquivo Histórico Militar (Military Historic Archive): PT AHM/DIV/1/24/245/31. Arquivo Tribunal de Contas (Archives of the Audit Court): ER 5451.

Instituto dos Arquivos Nacionais Torre do Tombo (Institute of National Archives/Torre do Tombo). Boxes: 62074, 62077, 62109 and 62150.

Instituto Nacional de Estatística, Balanças Gerais do Comércio do Reyno de Portugal com os seus Domínios Ultramarinos e Nações Estrangeiras de 1796-1797, 1799-1807, 1809-1831 (Portugal's Balance of Trade with Foreign Nations and Portuguese Colonies 1796-1797, 1799-1807, 1809-1831), Contadoria da Superintendência Geral dos Contrabandos e Descaminhos dos Reais Direitos.

\section{REFERENCES}

Ackerman, B. A. (1983): «What Is Neutral About Neutrality?». Ethics 93 (2), pp. 372-390. Bell, D. (2007): The First Total War: Napoleon's Europe and the Birth of Warfare as We Know It. New York: Houghton Mifflin Harcourt. 
Broadberry, S., and Harrison, M. (eds) (2005). The Economics of World War I. Cambridge, UK: Cambridge University Press.

Bukovansky, M. (2003): «American Identity and Neutral Rights from Independence to the War of 1812». International Organization 51, pp. 209-243.

Coates, D., and Heckelman, J. (1993): «Interest Groups and Investment: A Further Test of the Olson Hypothesis». Public Choice 117 (3-4), pp. 333-340.

Crouzet, F. (1964): «Wars, Blockade, and Economic Change in Europe, 1792-1815». Journal of Economic History 24 (4), pp. 567-588.

Davis, L. E., and Engerman, S. L. (2006): Naval Blockades in Peace and War: An Economic History since 1750. New York: Cambridge University Press.

Eloranta, J. (2002): «European States in the International Arms Trade, 1920-1937: The Impact of External Threats, Market Forces, and Domestic Constraints». Scandinavian Economic History Review 50 (1), pp. 44-67.

Esdaile, C. J. (1988): The Spanish Army in the Peninsular War. Manchester: Manchester University Press.

Esdaile, C. J. (2003): The Peninsular War: A New History. New York: Palgrave MacMillan.

Ferguson, N. (2001): The Cash Nexus: Money and Power in the Modern World, 1700-2000. New York: Basic Books.

Findlay, R., and O'Rourke, K. (2007): Power and Plenty: Trade, War, and the World Economy in the Second Millennium. Princeton: Princeton University Press.

Fisher, H. E. S. (1963): «Anglo-Portuguese Trade, 1700-1770». Economic History Review 16 (2), pp. 219-233.

FørLand, T. E. (1993): "The History of Economic Warfare: International Law, Effectiveness, Strategies». Journal of Peace Research 30 (2), pp. 151-162.

Gates, D. (2002): The Spanish Ulcer: A History of the Peninsular War. London: Pimlico.

Glick, R., and TAYlor, A. M. (2005): "Collateral Damage: Trade Disruption and the Economic Impact of War». NBER Working Paper, No. 11565.

Grainger, J. D. (2004): The Amiens Truce: Britain and Bonaparte, 1801-1803. Rochester, NY: Boydell.

Gray, V., and Lowery, D. (1988): "Interest Group Politics and Economic Growth in the U.S. States». The American Political Science Review 82 (1), pp. 109-131.

HANDEL, M. I. (1981): Weak States in the International System. London: F. Cass.

Harrison, M. (ed.) (1998): The Economics of World War II. Six Great Powers in International Comparisons. Cambridge, UK: Cambridge University Press.

Heckscher, E. F. (Harald Westergaard, ed.) (1922): The Continental System: an Economic Interpretation. Publications of the Carnegie Endowment for International Peace, Division of Economics and History. Oxford, London, New York: Clarendon Press.

Hetherington, B. W., and Kower, P. J. (2009): «A Reexamination of Lebergott's Paradox About Blockade Running During the American Civil War». The Journal of Economic History 69 (2), pp. 528-532.

HickeY, D. R. (1981): «American Trade Restrictions during the War of 1812». The Journal of American History 68 (3), pp. 517-538.

Joenniemi, P. (1998): «From Small to Smart: Reflections on the Concept of Small States». Irish Studies in International Affairs 9, pp. 61-62.

Kamen, H. (2003): Empire: How Spain Became a World Power, 1492-1763. New York: Harper Perennial.

KaRSH, E. (1988): Neutrality and Small States. London: Routledge.

KEEnE, C. A. (1978): «American Shipping and Trade, 1798-1820: The Evidence from Leghorn». Journal of Economic History 38 (3), pp. 681-700. 
Kennedy, P. (1998): The Rise and Fall of British Naval Mastery. Amherst, NY: Humanity Books.

Lydon, J. G. (1965): «Fish and Flour for Gold: Southern Europe and the Colonial American Balance of Payments». The Business History Review 39 (2), pp. 171-183.

Maddison, A. (1995): Monitoring the World Economy 1820-1992. Paris: OECD.

Maddison, A. (2001): The World Economy: A Millennial Perspective. Paris: OECD.

Meisel, A., and BARóN, J. D. (2010): «A Historical Analysis of Central Bank Independence in Latin America: The Colombian Experience, 1923-2008». Journal of Iberian and Latin American Economic History 26 (1), pp. 83-102.

Milward, A. S. (1965): The German Economy at War. London: Athlon Press.

Milward, A. S. (1977): War, Economy and Society 1939-1945. London: Allen Lane.

Milward, A. S. (2005): «Economic Warfare in Perspective», in J. Eloranta, and J. Ojala (eds), East-West Trade and the Cold War. Jyvaskyla: University of Jyvaskyla, pp. 201-207.

Moreira, M. C. (2007a): «The role of Quality: Spanish wool in Portuguese Trade in the Early 19th Century». Essays in Economic and Business History, vol. XXV published by the Journal of the Economic and Business Historical Society and L. Argyros School of Business and Economics Chapman University, Editor Lynne Pierson Doti.

Moreira, M. C. (2007b): «Tracking Down Signs of the Portuguese Fiscal-Military State 1762-1816», in R. T. Sánchez (ed.), War, Sate, and Development. Fiscal Military States in the Eighteenth Century. Pamplona, Spain: EUNSA, pp. 251-275.

Moreira, M. C. (2005): «La Importancia del Mercado Español en el Comercio Exterior Português (1796-1831)». Hispania Nova Revista de Historia Contemporánea no. 6, ISSN: 1138-7319.

Müller, L. (2001): «Swedish Shipping Industry: A European and Global Perspective, 1600-1800». Journal of History for the Public 6, pp. 30-47.

Müller, L. (2004): Consuls, Corsairs, and Commerce: The Swedish Consular Service and Long-Distance Shipping, 1720-1815. Uppsala: Uppsala Universitet.

NAYLOR, R. T. (2001): Economic Warfare: Sanctions, Embargo Busting, and Their Human Cost. Boston: Northeastern University Press.

O'Leary, J. P. (1985): «Economic Warfare and Strategic Economics». Comparative Strategy 5 (2), pp. 179-206.

Olson, M. (1982): The Rise and Decline of Nations: Economic Growth, Stagflation, and Social Rigidities. New Haven: Yale University Press.

O'Rourke, K. (2006): «The Worldwide Economic Impact of the French Revolutionary and Napoleonic Wars, 1793-1815». Journal of Global History 1 (1), pp. 123-149.

Rosecrance, R., and Lo, C.-C. (1996): «Balancing, Stability, and War: The Mysterious Case of the Napoleonic International System». International Studies Quarterly 40, pp. 479-500.

Ruppenthal, R. (1943): «Denmark and the Continental System». The Journal of Modern History 15 (1), pp. 7-23.

Thornton, M., and Ekelund, R. B. (2004): Tariffs, Blockades, and Inflation: The Economics of the Civil War. Wilmington, DE: Scholarly Resources Inc.

Turchin, P. (2008): «A Theory for Formation of Large Empires». Journal of Global History 4 (2), pp. 191-217.

Wise, S. R. (1991): Lifeline of the Confederacy: Blockade Running During the Civil War. Columbia, SC: University of South Carolina Press. 